\title{
Dyspozycje aksjologiczne nauczyciela - perspektywa ucznia
}

\section{KEYWORDS}

habitus of the teacher, values, pedagogical tactfulness

\begin{abstract}
Małgorzata Czapla, Dyspozycje aksjologiczne nauczyciela perspektywa ucznia [Axiological Dispositions of the Teacher - the Student's Perspective]. Kultura - Społeczeństwo Edukacja nr 2(20) 2021, Poznań 2021, pp. 341-358, Adam Mickiewicz University Press. ISSN 2300-0422, ISSN (Online) 2719-2717. DOI 10.14746/kse.2021.20.22
\end{abstract}

The articles justifies the need for constant care for the axiological dimension of education. The habitus of the modern teacher was analyzed in the perspective of axiological dispositions. The author's reconstructions of the respondents' views concerning their preferences regarding observable and repetitive teachers' behavior were categorized. These behaviors were indicators of the values which guided teachers in their work with students. An attempt was made to determine which axiological properties of teachers, expressed in the praxiological dimension, are particularly valued by today's youth. Analysis of the frequency of indications of the preferred teachers' behaviors helped to establish the hierarchy of these properties. The results of the diagnosis carried out on a sample of 903 respondents showed that teachers' pedagogical tactfulness, subject knowledge and good organization of work are mostly appreciated and expected by young people. In addition, attempts were made to identify differences in the respondents' preferences due to their interest profile, expressed in the choice of a specific field of academic studies. It has been established that it is the factor which differentiates students' preferences in relation to the teacher's axiological attributes. Significant relationships have been observed and the conclusions made valuable implications for pedeutology.

* ORCID: https://orcid.org/0000-0003-1781-8362. 


\section{Habiłus współczesnego nauczyciela - dylematy}

Problem habitusu w rozumieniu Pierre’a Bourdieu (Sztandar-Sztanderska, 2010), w odniesieniu do współczesnego nauczyciela, stanowi asumpt dla określenia pożądanych właściwości uczącego na miarę obecnych czasów. Atrybuty nauczycieli to przestrzeń o szerokiej semantyce, a badanie preferencji w tym zakresie jest procesem niezwykle złożonym, dotyczy bowiem wielu wymiarów. Wielowymiarowość profesji nauczycielskiej odnosi się do takich obszarów, jak kompetencje zawodowe, sposób pracy, stosunek do obowiązków zawodowych, cechy osobiste i przede wszystkim system wartości, czyli dyspozycje aksjologiczne nauczyciela. W niniejszym artykule zwrócono szczególną uwagę na ostatni z wymienionych obszarów i podjęto próbę namysłu nad statusem i rolą wartości, które ujawniają się w różnych kontekstach edukacyjnych.

W dyskursie dotyczącym aksjologii pedagogicznej często pojawia się problem redefinicji wartości. „Mówi się wręcz o kryzysie aksjologicznym i płynności aksjologicznej, próbuje się uzasadniać, że płynność i zmienność wartości jest nie tylko koniecznością dziejów, ale czymś pożytecznym dla rozwoju ludzkości” (Siewiora, 2017: 31).

Taki pogląd rodzi dylematy w rozważaniach na temat preferencji młodzieży dotyczących problemu wartości. Mogą one mieścić się w przestrzeni ponadczasowego i niezmiennego kapitału moralnego ludzkości, ale mogą również znaleźć się w obszarze zrelatywizowanych wartości. Ów relatywizm może wynikać z faktu zmian, jakim podlegają indywidualne systemy wartości w zależności od zmian ogólnospołecznych, ale również z faktu przemian psychicznych związanych z fazą życia człowieka. „Maria Tyszkowa (1990) uważa, że wartości pozostają w istotnej relacji do potrzeb (biologicznych, społeczno-kulturowych, psychologicznych) człowieka związanych z jego życiem, aktywnością i rozwojem w środowisku ludzi oraz ze stanem i sposobem uświadamiania i zaspokajania tych potrzeb $\mathrm{w}$ danych warunkach społeczno-kulturowych" (Kleszcz, 2011: 42).

Punkt wyjścia dla podjętych rozważań stanowią kategorie wartości. Odwołano się do klasycznych teorii wartości na przykład Maxa Schellera (Wędzińska, 2013: 31-43), czy Miltona Rokeacha (Karney, 2007). Nie ulega wątpliwości fakt, że wszelkie działania edukacyjno-wychowawcze powinny podlegać regulacji aksjologicznej za pomocą wartości: „(...) nie da się sensownie traktować edukacji poza systemem wartości, gdyż edukacja odwołuje się do wartości ogólnoludzkich, uniwersalnych, humanistycznych" (Denek, 1993: 22).

Jak zauważa Aleksander Nalaskowski, obecne czasy charakteryzują się, między innymi, próbą przeniknięcia nowych ideologii, norm i wartości w procesy edu- 
kacyjne (Nalaskowski, 2020). Wobec powyższego należałoby się zastanowić, jakie wartości stanowią obecnie fundament, na którym buduje się kulturę pedagogiczną i kulturę w relacjach międzyludzkich. Są one wyznacznikiem postaw wobec ludzi i rzeczy. Zazwyczaj wyrażają się w określonych wzorcach postępowania, czyli w działaniu. Niektórzy badacze twierdzą, że obecnie ma miejsce przewartościowanie wartości, a nawet swoista dewaluacja wartości uniwersalnych, które uważane są za anachroniczne i nieaktualne. Ich miejsce zajmują inne wartości. Wiąże się to z globalną rewolucją kulturową, która „dokonała fundamentalnej zmiany roli edukacji. Obecnie jej podstawowym celem nie jest już zdobywanie wiedzy obiektywnej, ale nabywanie wiedzy praktycznej (know-how) oraz umiejętności życiowych. Aby osiągnąć ten cel, trzeba, (...), zreformować edukację od środka” (Peeters, 2010: 208).

I tu nasuwa się pytanie, jakie stanowisko w tej kwestii prezentuje współczesna młodzież? Które założenia realizują się na poziomie mentalnym młodych ludzi? Przestrzenią szczególnie skłaniającą do myślenia o wartościach jest przestrzeń relacji w procesie kształcenia człowieka, a zwłaszcza obszar, w którym nauczyciel w relacji z uczniem wpływa na kształtujący się jego system wartości. Interioryzacja wartości wpisana jest w istotę pedagogiki. A możliwość wywierania wpływu stanowi jeden $\mathrm{z}$ najgłębszych fundamentów pedagogiki. Przyjmuje się zatem, że nauczyciele mają zobowiązania moralne wobec wychowanków. Uniwersalne wartości powinny prowadzić i definiować nauczyciela, a ustawiczna dbałość o ich respektowanie winna stanowić podstawę nowoczesnej pedagogiki, dla której główną osią jest kultura pedagogiczna, ukonstytuowana na owych wartościach. Misja zawodu nauczyciela polega na „wyzwoleniu olbrzymiego potencjału duchowego człowieka, przez który człowiek urzeczywistnia swoje człowieczeństwo” (Nalaskowski, 2020).

Nie jest możliwe realizowanie owej misji w oderwaniu od trwałych wartości, które niosą w sobie znaczenia powinnościowe i wskazują na to, co społecznie pożądane. Ponadto wpływają na proces kształtowania się idei i myślenie oraz stanowią doskonały kontekst dla percepcji różnych zjawisk społecznych. Stąd problem dyspozycji aksjologicznych nauczyciela, wpisany w misję i etos tego zawodu, wymaga wnikliwego namysłu, analizy oraz stanowi niezwykle ważki przedmiot rozważań naukowych badaczy. Jak zauważa Urszula Ostrowska, dorobek naukowy dotychczasowej aksjologii pedagogicznej jest bogaty. Istotny, bezpośredni lub pośredni wkład do rozwoju przesłanek konstruujących aksjologię pedagogiczną w Polsce wnieśli, między innymi: „K. Chałas, Cz. Czapów, K. Denek, W. Furmanek, J. Górniewicz, S. Hessen, J. Homplewicz, Jan Paweł II, W. Kaczyńska, K. Kotłowski, S. Kunowski, Z. Melosik, Z.K. Mysłakowski, B. Nawroczyński, K. Olbrycht, K. Os- 
trowska, U. Ostrowska, B. Suchodolski, W. Szczęsny, H. Świda-Ziemba, J. Tischner, W. Witkowski” (Ostrowska, 2017: 16 za: Maj, 2016: 90-91).

Szczególnie warto zwrócić uwagę na prace Krystyny Chałas (2003, 2011, 2016, 2017), Jarosława Michalskiego (2010, 2013, 2017), Aleksandra Nalaskowskiego (2006, 2009, 2013, 2020), Lecha Witkowskiego (2009, 2011), ale również Małgorzaty Kabat $(2017,2018)$, Ewy Kobyłeckiej $(2009,2020)$, czy Magdaleny Wędzińskiej (2017, 2018, 2019a, 2019b, 2020). Oczywiście, nie jest to lista zamknięta.

Poprzez swoje zachowanie człowiek wyraża i urealnia wartości. Zatem są one czynnikami determinującymi działania człowieka. Jan Kościuch, rozważając koncepcję wartości Miltona Rokeacha, zauważa, że problematyka wartości łączy się zwykle z problematyką postaw (Kościuch, 1983: 83-96). Postawa jest konstruktem złożonym. „Rokeach zdefiniował postawę jako względnie trwałą organizację przekonań dotyczących pewnego przedmiotu lub sytuacji predysponującą nas do reagowania na nie w określony sposób" (Kościuch, 1983: 83-96).

Pojęcie postawy jest jednym z kluczowych pojęć teoretycznych w naukach społecznych i bezpośrednio łączy się z pojęciem wartości (por. J. Reykowski, 1973 i S. Nowak, 1973: 22).

Na istotność związku postaw z wartościami wskazywali Theodore Newcomb, Ralph Turner i Philip Converse (1970), którzy twierdzili, że wartości mogą być rozpatrywane jako ostateczny efekt wielu procesów selekcji i uogólniania, których wynikiem jest stabilność oraz zorganizowanie indywidualnego zachowania. Na bezpośredni związek pojęcia postawy z pojęciem wartości wskazywał również Florian Znaniecki, który uważał, że „jeżeli postawy należy określić w odniesieniu do wartości danej zbiorowości, to znaczenie owych wartości dla uczestników zbiorowości trzeba ustalić, badając ich postawy. Zmiany kulturowe i zmiany psychologiczne należy wyjaśniać przyczynową współzależnością wartości i postaw” (Znaniecki, 1971: 413).

Postawa zaś pozostaje w bezpośrednim związku z zachowaniem. Zatem można przyjąć, że określone wartości wyrażają się w konkretnych zachowaniach, takich jak na przykład taktowność, uprzejmość, umiejętność przebaczania. Natomiast wartości kompetencyjne, którymi są na przykład zdolności, wiedza, twórcza wyobraźnia, realizują się w podejmowanych decyzjach, efektywnym uczeniu się, czy działalności twórczej. W tym przypadku wartości są motywacją do działania wyrażonego w konkretnym zachowaniu.

Postawa oraz zachowanie nauczyciela z założenia konstytuują się na fundamencie uznanych i przyjętych uniwersalnych wartości oraz norm współżycia społecznego. Wartości organizują praktyczną realizację procesu kształcenia człowieka. Szczególną uwagę warto w tym miejscu zwrócić na tak zwany takt pedagogiczny nauczyciela, mieszczący się w przestrzeni aksjologicznych uniwersaliów, o którym 
pisze między innymi Jarosław Michalski. Takt jest ważny ze względu na relacyjny charakter procesu kształcenia. Ponadto jest wyznacznikiem wspólnoty uczących się. Wskaźnikami wartości, którymi kieruje się taktowny nauczyciel w swojej pracy z uczniami, są możliwe do zaobserwowania i powtarzalne jego określone zachowania. Wartości cenione przez uczniów w nauczycielach, wyrażające się w zachowaniu i postawie nauczycieli, mogą stanowić prefigurację wizerunku nauczyciela o preferowanych dyspozycjach aksjologicznych. Na podstawie preferencji młodzieży można spróbować scharakteryzować pozytywny habitus współczesnego nauczyciela, odpowiadający jej potrzebom.

Wartości, którymi kieruje się w swojej pracy nauczyciel, są często internalizowane przez uczniów. Na tym polega moc sprawcza pedagogiki przykładu. Nie teoria, ale zachowania nauczycieli, czyli ich system wartości w działaniu najdobitniej przemawiają do młodzieży, która owe wartości dostrzega i interpretuje. To w dużej mierze nauczyciel jest multiplikatorem tychże wartości i pozytywnych postaw. Z tego powodu może stanowić dla ucznia swoisty model - wzór do naśladowania. I w ten sposób uruchamia się mechanizm modelowania, rozumiany jako proces, który zachodzi, ,jeśli ludzie zmieniają się pod wpływem obserwacji działań innych ludzi” (Konarzewski, 1982: 87). Istotą tego procesu jest zjawisko identyfikacji i naśladownictwa. „Naśladownictwo polega na przejmowaniu od innej osoby, która staje się wówczas modelem, zewnętrznych form zachowania oraz sposobów reagowania na różnorodne sytuacje, identyfikacja zaś na odwzorowywaniu cudzych stanów psychicznych, wewnętrznym utożsamianiu się z inną osobą, na współbrzmieniu uczuciowym, a więc przyjmowaniu od niej poglądów, postaw, ideałów, wartości" (Dudzikowa, 1987: 69).

Określone wartości, którymi kieruje się nauczyciel w swojej pracy sprawiają, że uczniowie cenią nauczyciela, który ma wówczas szansę stanowić ów model wzór do naśladowania.

\section{Cele badań}

Interioryzacja określonych wartości wpływa na decyzje i działania. Można zatem przyjąć, że uznane wartości wyzwalają zachowania korzystne zarówno dla tego, kto je praktykuje, jak i dla osób, do których są skierowane. Przyjmując powyższe założenie, sformułowano cele badań.

Po pierwsze, celem była próba ustalenia, na podstawie relacji z własnych obserwacji i doświadczeń badanych, jakimi wartościami kierował się w swojej pracy z uczniami ceniony przez nich nauczyciel. 
Drugim celem badań było rozstrzygnięcie, czy profil uczniów, wyrażający się w ich zainteresowaniach i wyborze określonego kierunku studiów, jest czynnikiem różnicującym preferencje uczniowskie w odniesieniu do dyspozycji aksjologicznych nauczyciela.

\section{Problemy}

Mając na uwadze powyższe cele, sformułowano dwa problemy badawcze. Po pierwsze, podjęto próbę ustalenia, jakimi wartościami kieruje się w swojej pracy ceniony przez młodzież nauczyciel? oraz które $z$ tych wartości sa dla badanych szczególnie ważne?

Po drugie, podjęto próbę rozstrzygnięcia, czy profil zainteresowań ucznia jest czynnikiem różnicującym preferencje dotyczące wartości?

Wskaźnikiem wartości, jakimi kieruje się ceniony przez badanych nauczyciel w swojej pracy z uczniami, były wypowiedzi badanych orzekające o wartościach, dokonane na podstawie długotrwałej obserwacji powtarzalnych, utrwalonych zachowań nauczycieli. Pewne zjawiska obserwowalne, w tym przypadku konkretne sposoby zachowań nauczycieli, mogą odpowiadać określonym wartościom.

$\mathrm{W}$ analizach uwzględniono również wskazania badanych na te kategorie wartości, które są przez nich osobiście szczególnie cenione w nauczycielach. Pozwoliło to ze zbioru cenionych wartości wyłonić te najważniejsze dla badanych.

Profil uczniów ustalono na podstawie danych pochodzących od badanych potwierdzających kierunek podjętych przez nich studiów. Wskaźnikiem zainteresowań medycznych ucznia jest podjęcie studiów medycznych na kierunku lekarskim. Wskaźnikiem zainteresowań związanych z kulturą fizyczną jest podjęcie studiów na kierunkach sport i fizjoterapia. Wskaźnikiem zainteresowań technicznych ucznia jest podjęcie studiów inżynierskich z informatyki. Wskaźnikiem zainteresowań humanistyczno-społecznych ucznia jest podjęcie studiów na kierunku pedagogika.

\section{Próba}

W przeprowadzonych badaniach wyjściowym założeniem dotyczącym doboru próby badawczej było kryterium profilu ucznia. Skoncentrowano się na dwóch grupach badanych: grupa o zainteresowaniach humanistyczno-społecznych oraz grupa o zainteresowaniach ścisłych. Badaniami objęto studentów pierwszego roku, studiujących cztery dziedziny w ramach trzech obszarów naukowych. Te obszary to: obszar 
nauk medycznych i nauk o zdrowiu oraz nauk o kulturze fizycznej; obszar nauk technicznych oraz obszar nauk społecznych. Studiowane dziedziny to: dziedzina nauk medycznych (medycyna), dziedzina nauk o kulturze fizycznej (sport i fizjoterapia), dziedzina nauk technicznych (informatyka) oraz dziedzina nauk społecznych (pedagogika).

Badaniom poddano studentów studiów inżynierskich $\mathrm{z}$ informatyki (265 osób); studentów studiujących nauki o kulturze fizycznej w ramach kierunków sport i fizjoterapia (207 osób); studentów studiujących medycynę (58osób) oraz studentów studiujących pedagogikę (373 osoby). Łącznie badaniami objęto 903 studentów na pierwszym roku, co stanowi materiał empiryczny.

\section{Metoda}

Przeprowadzono badania jakościowe polegające na analizie treści pisemnych wypowiedzi badanych. Wyrażane w nich spostrzeżenia i stwierdzenia dotyczyły wartości, jakimi według badanych kieruje się w swojej pracy z uczniami ceniony przez nich nauczyciel. Ponadto badani wskazywali na te wartości szczególnie przez nich preferowane.

Opracowanie jakościowe zebranego materiału badawczego polegało na precyzyjnej identyfikacji, a następnie odpowiedniej klasyfikacji pisemnych wypowiedzi badanych do określonej kategorii wartości (Silverman, 2012). „Analizę treści można określić jako technikę badawczą, która w sposób zobiektywizowany ustala i opisuje cechy językowe tekstów po to, aby na tej podstawie wnioskować o niejęzykowych własnościach ludzi i agregatów społecznych" (Mayntz, Holm, Hubner, 1985: 193). „W tym, co mówią i piszą, ludzie dają świadectwo swoim dążeniom, postawom, ocenom sytuacji, swojej wiedzy oraz milcząco przyjmowanym założeniom dotyczącym otaczającego świata" (Mayntz, Holm, Hubner, 1985: 192).

Celem analizy treści jest identyfikacja i klasyfikacja treści lub znaczeń określonych konfiguracji językowych - słów, zwrotów, zdań lub dłuższych wypowiedzi. „Narzuca się tu pytanie, jak można obiektywnie ustalić znaczenia konfiguracji słownych zawartych w tekście. Skąd, konkretnie mówiąc, osoba dokonująca analizy treści wie, co oznacza określony znak językowy w danym tekście, jaką treść nadaje mu nadawca? Niestety, osoba dokonująca analizy treści opiera się z reguły na własnym intuicyjnym rozumieniu języka” (Mayntz, Holm, Hubner, 1985: 194).

W przeprowadzonych badaniach, poszukując wyjścia z tej sytuacji, zastosowano tak zwaną metodę sędziów kompetentnych, to znaczy poproszono niezależną osobę o dokonanie szczegółowej analizy treści pisemnych wypowiedzi wybranych 
badanych. „Analizę treści stosuje się właśnie wówczas, gdy zdobycie danych o zjawiskach niejęzykowych nie jest możliwe lub, gdy się sądzi, że ich kształt językowy jest wskaźnikiem bardziej jednoznacznym niż jakiekolwiek inne dostępne wskaźniki. Wnioski w takich przypadkach muszą znajdować oparcie $\mathrm{w}$ teorii, która mówi, w jakich okolicznościach określone postawy, intencje, wartości itd. przyjmują określone formy językowe" (Mayntz, Holm, Hubner, 1985: 195).

Uzyskane dane opracowano zgodnie z procedurą kodowania danych jakościowych. Dla analizy jakościowej jest to procedura analogiczna do statystycznej analizy danych ilościowych. Zakodowane dane jakościowe poddano digitalizacji, tworząc bazę danych ilościowych. Następnie zgromadzony obszerny materiał badawczy poddano szczegółowej analizie statystycznej.

Aby zbadać, czy istnieje związek pomiędzy profilem zainteresowań młodzieży a preferowanymi przez nią wartościami, którymi kierują się cenieni nauczyciele, zastosowano test niezależności chi-kwadrat $\left(\chi^{2}\right)$ (Creswell, 2013; Witkowski, 2010; Ferguson, Takane, 2003; Nachmias, Nachmias, 2001; Juszczyk, 2001).

\section{Wyniki}

Na podstawie analizy treści pisemnych wypowiedzi badanych wyodrębniono kategorie dyspozycji aksjologicznych nauczycieli cieszących się uznaniem młodzieży. Są to:

1) takt pedagogiczny, wyrażający się poprzez określone właściwości nauczyciela o charakterze pozytywnie usposabiającym do uczniów;

2) kompetentność w zakresie wiedzy przedmiotowej;

3) rozbudzanie ambicji w uczniach poprzez własną ambicję;

4) umiejętność kształtowania kultury uczenia się poprzez systematyczną pracę;

5) pozytywna pasja jako wysiłek twórczy;

6) praktyka, czyli wykorzystanie wiedzy w działaniu;

7) umiejętność dostrzeżenia zdolności ucznia i ukierunkowanie ich rozwoju, mające w efekcie doprowadzić do osiągnięcia indywidualnego sukcesu na miarę własnych możliwości;

8) dobra atmosfera i pomoc;

9) dobre wyniki nauczania - uczenia się.

Wypowiedzi badanych były wielokrotne, to znaczy - w poszczególnych wypowiedziach można było odnaleźć kilka kategorii cenionych wartości, którymi kieruje się nauczyciel w swojej pracy z uczniami. Wyniki analiz przeprowadzonych na całej próbie badanych przedstawiono w tabeli 1 . 
Tabela 1. Wartości cenione w nauczycielu

\begin{tabular}{|c|l|r|r|}
\hline $\begin{array}{c}\text { Kategoria } \\
\text { wartości }\end{array}$ & \multicolumn{1}{|c|}{ Wartości cenione w nauczycielu } & $n$ & $\%$ \\
\hline 1 & taktowność & 626 & 69,32 \\
\hline 2 & wiedza przedmiotowa & 272 & 30,12 \\
\hline 3 & ambicja & 23 & 2,55 \\
\hline 4 & praca & 208 & 23,03 \\
\hline 5 & wysiłek twórczy i pasja & 55 & 6,09 \\
\hline 6 & wykorzystanie wiedzy w działaniu & 44 & 4,87 \\
\hline 7 & rozwijanie zdolności ucznia & 2 & 0,22 \\
\hline 8 & pomoc & 124 & 13,73 \\
\hline 9 & dobre wyniki nauczania - uczenia się & 56 & 6,20 \\
\hline Brak odpowiedzi & 158 & 17,50 \\
\hline
\end{tabular}

W celu wyłonienia wartości szczególnie cenionych i ważnych dla badanych, dokonano analizy powtórnych wypowiedzi badanych dotyczących ich osobistych preferencji w tym zakresie. Ustalono, które wartości cenione w nauczycielach są dla badanych szczególnie ważne i znaczące. Uzyskane wyniki przedstawiono w tabeli 2 (wypowiedzi udzielane przez badanych były również wielokrotne).

Tabela 2. Wartości szczególnie ważne i znaczące dla uczniów

\begin{tabular}{|c|l|r|r|}
\hline $\begin{array}{c}\text { Kategoria } \\
\text { wartości }\end{array}$ & \multicolumn{1}{|c|}{ Wartości szczególnie ważne dla uczniów } & $n$ & $\%$ \\
\hline 1 & taktowność & 468 & 51,83 \\
\hline 2 & wiedza przedmiotowa & 127 & 14,06 \\
\hline 3 & ambicja & 6 & 0,66 \\
\hline 4 & praca & 102 & 11,30 \\
\hline 5 & wysiłek twórczy i pasja & 24 & 3,43 \\
\hline 6 & wykorzystanie wiedzy w działaniu & 1 & 2,66 \\
\hline 7 & rozwijanie zdolności ucznia & 69 & 0,11 \\
\hline 8 & pomoc & 23 & 7,64 \\
\hline 9 & dobre wyniki nauczania - uczenia się & 221 & 2,55 \\
\hline Brak odpowiedzi & 24,47 \\
\hline
\end{tabular}

Częstości wskazań kategorii wartości szczególnie cenionych, ważnych i znaczących dla badanych są zasadniczo zbieżne z częstościami odpowiedzi orzekających o wartościach, jakimi kieruje się ceniony nauczyciel. Hierarchia wartości $\mathrm{w}$ obu przypadkach jest zachowana $\mathrm{z}$ niewielkimi fluktuacjami w ramach takich 
kategorii, jak: wysiłek twórczy i pasja, wykorzystanie wiedzy w działaniu oraz dobre wyniki nauczania - uczenia się. Badani cenią osobiście wyżej takie dyspozycje nauczycielskie, jak pasja i wykorzystanie wiedzy w praktyce. Natomiast dążenie do osiągnięcia dobrych wyników nauczania stanowi kategorię generalnie cenną u nauczycieli, choć osobiście dla badanych ma ona znaczenie nieco mniejsze.

Dalszej analizie poddano preferencje młodzieży dotyczące wartości w poszczególnych grupach profilu zainteresowań. Wypowiedzi poszczególnych badanych w każdej z grup zawierały, podobnie jak w powyżej przedstawionych analizach, różne kategorie wartości, to znaczy były wielokrotne, zatem uzyskane wyniki analiz częstości wskazań nie sumują się do stu procent. Wyniki przedstawiono w tabelach 3 i 4. Procent częstości wskazań na daną kategorię wartości obliczono $\mathrm{w}$ stosunku do liczebności badanych $\mathrm{w}$ danej grupie profilu zainteresowań, dla każdej odpowiedzi i kierunku studiów z osobna.

$\mathrm{Na}$ podstawie przeprowadzonych analiz z zastosowaniem testu chi-kwadrat $\left(\chi^{2}\right)$ stwierdzono wysoce istotne zależności pomiędzy profilem zainteresowań a cenionymi wartościami.

Tabela 3. Wartości cenione w nauczycielu a profil zainteresowań uczniów

\begin{tabular}{|c|c|c|c|c|c|c|c|c|c|}
\hline \multirow{3}{*}{$\begin{array}{l}\text { Kategoria } \\
\text { wartości }\end{array}$} & \multirow{3}{*}{$\begin{array}{l}\text { Wartości cenione } \\
\text { w nauczycielu }\end{array}$} & \multicolumn{8}{|c|}{ Profil zainteresowań } \\
\hline & & \multicolumn{2}{|c|}{ informatyka } & \multicolumn{2}{|c|}{ pedagogika } & \multicolumn{2}{|c|}{$\begin{array}{l}\text { nauki o kultu- } \\
\text { rze fizycznej }\end{array}$} & \multicolumn{2}{|c|}{ medycyna } \\
\hline & & $n$ & $\%$ & $n$ & $\%$ & $n$ & $\%$ & $n$ & $\%$ \\
\hline 1 & taktowność & 129 & 48,68 & 290 & 77,75 & 161 & 77,78 & 46 & 79,31 \\
\hline 2 & wiedza przedmiotowa & 82 & 30,94 & 99 & 26,54 & 66 & 31,88 & 25 & 43,10 \\
\hline 3 & ambicja & 10 & 3,77 & 9 & 2,41 & 4 & 1,93 & 0 & 0,00 \\
\hline 4 & praca & 51 & 19,25 & 85 & 22,79 & 59 & 28,50 & 13 & 22,41 \\
\hline 5 & $\begin{array}{l}\text { wysiłek twórczy } \\
\text { i pasja }\end{array}$ & 28 & 10,57 & 12 & 3,22 & 15 & 7,25 & 0 & 0,00 \\
\hline 6 & $\begin{array}{l}\text { wykorzystanie wiedzy } \\
\text { w działaniu }\end{array}$ & 12 & 4,53 & 18 & 4,83 & 13 & 6,28 & 1 & 1,72 \\
\hline 7 & $\begin{array}{l}\text { rozwijanie zdolności } \\
\text { ucznia }\end{array}$ & 2 & 0,75 & 0 & 0,00 & 0 & 0,00 & 0 & 0,00 \\
\hline 8 & pomoc & 18 & 6,79 & 59 & 15,82 & 42 & 20,29 & 5 & 8,62 \\
\hline 9 & $\begin{array}{l}\text { dobre wyniki naucza- } \\
\text { nia - uczenia się }\end{array}$ & 11 & 4,15 & 23 & 6,17 & 20 & 9,66 & 2 & 3,45 \\
\hline \multicolumn{2}{|l|}{ Suma } & 343 & & 595 & & 380 & & 92 & \\
\hline \multicolumn{2}{|l|}{$n$} & & 265 & & 373 & & 207 & & 58 \\
\hline
\end{tabular}


Wykazano na podstawie testu $\chi^{2}$, że istnieje zależność pomiędzy profilem zainteresowań młodzieży a preferowanymi przez nią wartościami, Związek pomiędzy tymi zmiennymi jest wysoce istotny statystycznie (na poziomie $p=0,000001$ ).

Najwyższą częstość wskazań w kategorii taktowność możemy zaobserwować u studiujących medycynę - 79,31\%, a najniższą u informatyków - 48,68\%. Wiedzę przedmiotową najwyżej cenią u nauczycieli medycy - 43,10\%, najrzadziej wskazywali na tę wartość pedagodzy - 26,54\%. 3,77\% badanych informatyków ceni ambicję u nauczyciela, podczas gdy medycy w ogóle nie uwzględnili tej wartości jako cennej dla nich. Systematyczna praca okazała się najwyżej ceniona przez studiujących nauki o kulturze fizycznej - 28,50\% wskazań. Natomiast wysiłek twórczy i pasję najwyżej cenią informatycy - 10,57\%, zaś medycy tej wartości w ogóle nie wskazali. Na wykorzystanie wiedzy w działaniu najczęściej wskazywali studiujący AWF - 6,28\%. Kategoria wartości, jaką jest rozwijanie zdolności ucznia okazała się najmniej ceniona przez badanych; zaobserwowano całkowity brak wskazań na tę wartość we wszystkich kategoriach profilu zainteresowań, z wyjątkiem informatyków - 0,75\%. Pomoc jest bardziej preferowana wśród studiujących AWF - 20,29\% niż wśród informatyków - 6,79\%. Dążenie do osiągania dobrych wyników nauczania było bardziej preferowane wśród zainteresowanych kulturą fizyczną - 9,66\% niż wśród medyków - 3,45\%.

$\mathrm{Na}$ podstawie analizy treści pisemnych wypowiedzi badanych wyłoniono ze zbioru cenionych przez nich wartości te szczególnie ważne i znaczące oraz ustalono ich hierarchię. Następnie sprawdzono, czy profil zainteresowań różnicuje preferencje młodzieży. Wyniki przedstawiono w tabeli 4.

Zależność pomiędzy profilem zainteresowań a częstością wskazań określonych kategorii wartości szczególnie ważnych dla badanych jest wysoce istotna statystycznie (na poziomie $p=0,000041$ ).

Największy procent odpowiedzi w kategorii taktowność jest udziałem pedagogów - 63,00\%, najmniejszy informatyków - 32,08\%. Wiedzę przedmiotową najwyżej cenią informatycy - 18,87\%, najniżej pedagodzy - 10,19\%. Praca jest najczęściej preferowaną wartością w grupie studiujących AWF - 14,49\%. Dla informatyków istotne znaczenie ma wysiłek twórczy i pasja - 6,42\%, podczas gdy medycy nie uznali tej wartości za ważną.

Umiejętność wykorzystywania wiedzy w działaniu - 3,86\%, pomoc - 10,63\% oraz dobre wyniki nauczania - uczenia się - 3,86\% są wartościami, na które najczęściej wskazywała młodzież studiująca nauki o kulturze fizycznej.

Poniżej przytoczono przykładowe wypowiedzi badanych opisujące najczęściej wskazywane, czyli najbardziej preferowane kategorie wartości, to znaczy takt pedagogiczny, wiedzę przedmiotową i pracę. 
Tabela 4. Wartości szczególnie ważne i znaczące dla uczniów w kategoriach profilu zainteresowań

\begin{tabular}{|c|c|c|c|c|c|c|c|c|c|}
\hline \multirow{3}{*}{$\begin{array}{c}\text { Kategoria } \\
\text { wartości }\end{array}$} & \multirow{3}{*}{$\begin{array}{l}\text { Wartości szczególnie } \\
\text { cenione i ważne dla } \\
\text { uczniów }\end{array}$} & \multicolumn{8}{|c|}{ Profil zainteresowań } \\
\hline & & \multicolumn{2}{|c|}{ informatyka } & \multicolumn{2}{|c|}{ pedagogika } & \multicolumn{2}{|c|}{$\begin{array}{c}\text { nauki } \\
\text { o kulturze } \\
\text { fizycznej }\end{array}$} & \multicolumn{2}{|c|}{ medycyna } \\
\hline & & $n$ & $\%$ & $n$ & $\%$ & $n$ & $\%$ & $n$ & $\%$ \\
\hline 1 & taktowność & 85 & 32,08 & 235 & 63,00 & 116 & 56,04 & 32 & 55,17 \\
\hline 2 & wiedza przedmiotowa & 50 & 18,87 & 38 & 10,19 & 32 & 15,46 & 7 & 12,07 \\
\hline 3 & ambicja & 3 & 1,13 & 1 & 0,27 & 2 & 0,97 & 0 & 0,00 \\
\hline 4 & praca & 24 & 9,06 & 44 & 11,80 & 30 & 14,49 & 4 & 6,90 \\
\hline 5 & $\begin{array}{l}\text { wysiłek twórczy } \\
\text { i pasja }\end{array}$ & 17 & 6,42 & 5 & 1,34 & 9 & 4,35 & 0 & 0,00 \\
\hline 6 & $\begin{array}{l}\text { wykorzystanie wiedzy } \\
\text { w działaniu }\end{array}$ & 5 & 1,89 & 9 & 2,41 & 8 & 3,86 & 2 & 3,45 \\
\hline 7 & $\begin{array}{l}\text { rozwijanie zdolności } \\
\text { ucznia }\end{array}$ & 1 & 0,38 & 0 & 0,00 & 0 & 0,00 & 0 & 0,00 \\
\hline 8 & pomoc & 13 & 4,91 & 31 & 8,31 & 22 & 10,63 & 3 & 5,17 \\
\hline 9 & $\begin{array}{l}\text { dobre wyniki naucza- } \\
\text { nia - uczenia się }\end{array}$ & 5 & 1,89 & 9 & 2,41 & 8 & 3,86 & 1 & 1,72 \\
\hline \multicolumn{2}{|l|}{ Suma } & 203 & & 372 & & 227 & & 49 & \\
\hline \multicolumn{2}{|l|}{$n$} & & 265 & & 373 & & 207 & & 58 \\
\hline
\end{tabular}

Takt pedagogiczny nauczyciela badani najczęściej określali za pomocą następujących wyrażeń: szacunek do ucznia, szczerość w relacji, lojalność, słowność, życzliwość, empatia, uczciwość, sprawiedliwość, współpraca, otwartość, opanowanie i spokój, cierpliwość, zrozumienie, zaufanie, traktowanie ucznia na równi ze sobą, obiektywizm, zainteresowanie uczniem, sympatia, wyrozumiałość, miłe usposobienie, obycie, punktualność, szanowanie czasu ucznia, uczynność, otwartość intelektualna, kultura osobista. U badanych o zainteresowaniach społeczno-humanistycznych dodatkowo pojawiły się takie właściwości taktownego nauczyciela, jak: tolerancyjny, akceptujący, swobodny, panujący nad emocjami, bezpośredni, radosny, zatroskany, etyczny, bezinteresowny i szlachetny, liberalny partner. Zainteresowani kulturą fizyczną cenili w nauczycielu komunikatywność, że nie oceniał powierzchownie, był wnikliwy, doceniający wysiłek, pozytywny. Medycy cenili obok wyżej wymienionych właściwości taktownego nauczyciela także pomysłowość, pozytywny dystans, zasadniczość, rozwagę, pokorę, ludzką przyzwoitość, umiejętność przyznania się do tego, że czegoś nie wie, emanujące dobro.

Drugą, w kolejności częstości wskazań, wartością jest wiedza przedmiotowa. Informatycy deklarowali, że cenią nauczyciela zaangażowanego w przekazywanie 
rzetelnej wiedzy, wzbudzającego zainteresowanie przedmiotem, mądrego, kompetentnego, stawiającego na naukę i samokształcenie (self-made man), posługującego się konkretem, szanującego swój przedmiot fachowca, profesjonalistę. Cenili uczenie logicznego myślenia zamiast postępowania według schematu, szanowali podejmowanie prób zrozumienia i kształcenia młodych umysłów, umiejętność dzielenia się wiedzą, jasny przekaz, kreatywność, rozwój intelektualny. Studiujący pedagogikę cenili nauczyciela, który wie o czym mówi, motywuje do nauki, jest autorytetem w swojej dziedzinie, wykazuje fascynację światem, miłość do wiedzy, dba o przepływ informacji. Dla zainteresowanych kulturą fizyczną dodatkowo ważne były: chęć przekazania swojego doświadczenia i dobre przygotowanie do zajęć, wyposażenie uczniów w nowe treści, zachęcanie do rozwoju, rozpoznanie i przekazanie wiedzy potrzebnej uczniom. Dla studentów medycyny wiedza jako wartość nadrzędna wyrażała się w profesjonalizmie i kompetencjach. Ponadto badani z tej grupy cenili prosty przekaz informacji ułatwiający zapamiętywanie.

Trzecią główną wartością cenioną przez badanych jest praca. Informatycy deklarują, że cenią solidną, ciężką pracę, zapał do pracy, pracowitość nauczycieli, widoczny wysiłek wkładany w zajęcia, rzetelność, skrupulatność, poczucie zobowiązania, determinację, sumienność, systematyczność, dokładność, dyscyplinę, konsekwencję i wytrwałość, poświęcenie, gorliwość, regularność, obowiązkowość, zdecydowanie, wymaganie od siebie i innych, poświęcenie na rzecz pracy i nauki ucznia. Pedagodzy dodatkowo podkreślają dobrą organizację pracy i zaangażowanie w pracę, ciekawy sposób prowadzenia lekcji, pilność, dociekliwość, terminowość. Traktują też pracę jako misję. Studenci wychowania fizycznego wiążą pracę z satysfakcją, cenią w nauczycielu zamiłowanie do pracy i koncentrację na pracy, uważają, że z pracy można czerpać wiele radości. Badani o zainteresowaniach medycznych są pełni uznania dla nauczycieli lubiących swoją pracę oraz takich, jak sami określają, którym się chce pracować. Często używają określeń sukcesywność i skuteczność w pracy.

\section{Wnioski}

Wyniki badań skłaniają do namysłu, co właściwie wyznacza w naszym życiu hierarchię wartości? Być może sposób myślenia swoistymi kategoriami, których cechą jest to, że wykluczają inne kategorie. W podjętych rozważaniach na temat dyspozycji aksjologicznych nauczyciela z pewnością należałoby wziąć pod uwagę jeszcze więcej zmiennych, również tych ukrytych, żeby zrozumieć naturę i rozmiary zjawiska internalizacji wartości. „W konkretnych sytuacjach wartości są 
aktywnymi elementami rzeczywistości ludzkiej, angażując człowieka w sferę określonych działań. Uznanie wartości narzuca określone powinności, konieczność określonych zachowań. Wszelkie decyzje, dążenia, spory, konflikty międzyludzkie, zakładają opowiedzenie się po stronie określonych wartości, a pozostanie obojętnym pod tym względem oznaczałoby rezygnację z wszelkich dążeń, wyrzeczenie się swego człowieczeństwa" (Gołaszewska, 1978: 87).

Wyniki badań pozwoliły wstępnie określić, jakich nauczycieli potrzebuje i ceni współczesna młodzież ze względu na wartości, którymi kierują się oni w swojej pracy dydaktyczno-wychowawczej. Ponadto pozwoliły ustalić hierarchię szczególnie cenionych wartości na podstawie zachowań nauczycieli, czyli ich systemu wartości w działaniu. Pomimo różnic w częstościach wskazań pomiędzy studiującymi informatykę, pedagogikę, nauki o kulturze fizycznej oraz medycynę, zaobserwowano, że najczęściej wskazywanymi kategoriami wartości, przez wszystkie grupy badanych, były w kolejności: taktowność, wiedza przedmiotowa oraz praca. Uczniowie szukają w nauczycielu kogoś, kto jest taktowny, dysponuje wiedzą, jest merytoryczny oraz zauważa i ceni wysiłek związany z pracą w procesie uczenia się.

Uczący się oczekują, potrzebują i wymagają bezpośrednich wartościowych relacji, a te można zbudować na fundamencie aksjologii pedagogicznej, ze szczególnym uwzględnieniem kultury zawodowej nauczyciela, a zwłaszcza taktu pedagogicznego, będącego pochodną indywidualnych dyspozycji aksjologicznych nauczyciela. Takt pedagogiczny, jak określa Jarosław Michalski, „to podstawowy czynnik w sztuce nauczycielskiego działania, polegający na odnoszeniu się do uczniów z odczuwanym przez nich szacunkiem, wyznaczając zarazem rozumienie podmiotowości przez wszystkich uczestników rzetelnego procesu wychowania" (Michalski, 2013).

Wartość, jaką jest taktowność nauczyciela w relacji z uczniem badani cenią najwyżej.

Często można usłyszeć, że obecnie w edukacji nie chodzi o to, żeby nauczyciel skupiał się na transmisji informacji, uczniowie nie potrzebują dostarczyciela informacji. Wyniki badań pokazały jednak wyraźnie, że uczniowie cenią nauczyciela merytorycznego i oczekują od niego uporządkowanych informacji, jak również wskazówek odnośnie do poruszania się w zalewie informacji. Tym bardziej że „przeciętny absolwent szkoły średniej jest gwałtownym, niespokojnym, roztargnionym młodzieńcem z umysłem jak strach na wróble zrobionym z najróżniejszych strzępów, które nie dają się ułożyć w jakikolwiek kształt. Nie ma pojęcia o wiedzy; nie wie, kiedy coś wie, ani nie wie, kiedy nie wie. Czuje chroniczny lęk, że oczekuje się odeń, iż będzie coś wiedział i jego pretensjonalne zachowanie ma na celu ukrycie faktu, że nie ma o niczym bladego pojęcia. Na przemian prezentuje 
gadatliwe wynurzenia i okresy wykrętnego milczenia. Przyjmuje autorytatywny ton mówiąc o ostatnich wydarzeniach politycznych i recytuje gotowe banały, jakby to były jego oryginalne odkrycia. Nie umie czytać, pisać, ani korzystać ze słownika. Jest przebiegły; wykazuje cynizm dekadenckiego dorosłego człowieka i łatwowierność małego dziecka. Zachowuje się głośno, agresywnie, wojowniczo. Jego głównym celem jest udowodnić, że niczego się nie boi, ponieważ tak naprawdę wszystko napawa go śmiertelnym lękiem" (Nalaskowski, 2020: 35-36; Rand, 2003: 9).

Dlatego, nie można pozbawić młodych ludzi merytorycznego wsparcia i przewodnictwa. Młodzież potrzebuje nie tylko mapy, ale nade wszystko uważności ze strony dorosłych, dysponujących rzetelną wiedzą.

Niemniej ważnym atrybutem aksjologicznym jest praca. Ceniony nauczyciel potrafi motywować uczniów do pracy, nadawać jej sens, ponadto sam cechuje się pracowitością i wiarą $\mathrm{w}$ to, że ciężka, systematyczna i sumienna praca przyniesie wymierne efekty.

Trzy fundamentalne wartości: takt pedagogiczny, wiedza i praca wyznaczają habitus cenionego nauczyciela. Wnioski płynące z badań są zbieżne ze stanowiskiem Marguerite Peeters odnośnie do oczekiwań młodzieży w stosunku do dorosłych, w tym zwłaszcza nauczycieli. Badaczka zajmująca się kluczowymi pojęciami, wartościami i mechanizmami globalizacji, podkreśla, że „wśród młodzieży daje się zauważyć nieokreślone i spontaniczne pragnienie powrotu do postawy zdroworozsądkowej, jednak pragnienie to rzadko zostaje zaspokojone, ponieważ starsi nie potrafią zapewnić im kierownictwa, którego młodzi poszukująa" (Peeters, 2010: 20).

Wnioski płynące z badań uzasadniają ustawiczną potrzebę dbałości o wymiar aksjologiczny edukacji. Uporządkowana, rzetelna wiedza, praca, a nade wszystko takt wygrywają w konfrontacji z pozornie tylko pożądanymi nowymi paradygmatami, oderwanymi od wartości uniwersalnych. Uczniowie potrzebują nauczycieli oddanych swej profesji i z zasadami respektowanymi we wszystkich wymiarach ich działalności, opartymi na uznanych, trwałych wartościach i regułach życia społecznego. Ponadto przejrzyste i przewidywalne zasady postępowania umożliwiają rozwój, dając poczucie bezpieczeństwa. Zatem w procesie kształcenia nauczycieli należałoby uwzględnić treści dotyczące aksjologii pedagogicznej, a zwłaszcza taktu pedagogicznego. Trudno budować wartościowe relacje interpersonalne bez tej wiedzy. Wszystko co dzieje się w szkole, nie tylko w procesie nauczania - uczenia się, ale generalnie w przestrzeni relacji międzyludzkich, powinno odbywać się zgodnie z logiką wartości. „W czasach relatywizacji zasad i norm współżycia między ludźmi, mnożących się patologii, zaniku potrzeb duchowych, rośnie zainteresowanie tym, co ważne, cenne, niezmienne. Współczesna szkoła może uczyć 
podopiecznych rozumienia i świadomego wyboru wartości. W placówkach oświatowych potrzebni są nauczyciele o wysokich kompetencjach aksjologicznych" (Pasterniak-Kobyłecka, 2018: 47).

Naturą pedagogiki jest dbałość o utrzymanie norm moralnych. Chyba nikt z nas nie chce się przyczynić do budowy takiego społeczeństwa, w którym pryncypia nic nie znaczą. Wszystkim nam potrzeba pewnej stałości.

\section{Bibliografia}

Chałas K. (2011), Moc wychowawcza przypadkowych zdarzeń w świetle introcepcji wartości, Kielce.

Chałas K. (2003), Wychowanie ku wartościom. Elementy teorii i praktyki, Lublin-Kielce.

Chałas K. (2017), Wartości w programie wychowawczym szkoły służące integralnemu rozwojowi $i$ wychowaniu ucznia, Warszawa.

Chałas K., Maj A. (red.) (2016), Encyklopedia aksjologii pedagogicznej, Radom.

Creswell J.W. (2013), Projektowanie badań naukowych. Metody jakościowe, ilościowe i mieszane, wydanie I, Kraków.

Denek K. (1993), Wartości i ich znaczenie w edukacji szkolnej i naukach o niej, Ruch Pedagogiczny, 5, s. 33-48.

Denek K. (2000), Aksjologiczne aspekty edukacji szkolnej, Toruń.

Dudzikowa M. (1987), Wychowanie przez aktywne uczestnictwo, Warszawa.

Ferguson G.A., Takane Y. (2003), Analiza statystyczna w psychologii i pedagogice, Warszawa.

Gołaszewska M. (1978), Internalizacja wartości, Etyka, 16, s. 81-102.

Juszczyk S. (2001), Statystyka dla pedagogów, Toruń.

Kabat M. (2017), Wartości w zawodzie nauczyciela - wykorzystanie systemowej metody analizy pojęć wieloznacznych, Zeszyty Naukowe Wyższej Szkoły Humanitas, Pedagogika, 14, s. 115-126.

Kabat M. (2018), Umiejętności i wartości w zawodzie nauczyciela, Prima Educatione, 2, s. 23-33.

Karney J.E. (2007), Psychopedagogika pracy, Warszawa.

Kleszcz M. (2011), Postawa twórcza a hierarchia wartości młodego pokolenia, Katowice.

Kobyłecka E. (2009), Nauczyciele i uczniowie gimnazjum wobec wyboru wartości. Między pewnościa a zwątpieniem, Zielona Góra.

Kobyłecka E. (2020), Edukacja aksjologiczna dziecka w środowiskach wychowawczych. Współczesne problemy, Kraków.

Konarzewski K. (1982), Podstawy teorii oddziaływań wychowawczych, Warszawa.

Kościuch J. (1983), Koncepcja wartości Miltona Rokeacha, Studia Philosophiae Christianae, 19/1, s. $83-96$.

Łobocki M. (1993), Pedagogika wobec wartości, [w:] B. Śliwerski (red.), Kontestacje pedagogiczne, Kraków, s. 125-135.

Maj A. (2016), Aksjologia pedagogiczna, [w:] K. Chałas (red.), Encyklopedia aksjologii pedagogicznej, Radom, s. 87-91.

Mayntz R., Holm K., Hubner P. (1985), Wprowadzenie do metod socjologii empirycznej, Warszawa.

Michalski J. (2010), Takt pedagogiczny w sztuce nauczycielskiego działania, Warszawa.

Michalski J. (2013), Rzecz o takcie pedagogicznym nauczyciela, Warszawa. 
Michalski J. (2017), Takt pedagogiczny jednym ze sposobów na skuteczne wychowywanie do wartości, https://opoka.org.pl/biblioteka/I/ID/db201708_wywiad_wychowanie.html, dostęp: 26.09.2017.

Morbitzer J. (2007), Edukacja wspierana komputerowo a humanistyczne wartości pedagogiki, Kraków.

Nachmias C.F., Nachmias D. (2001), Metody badawcze w naukach społecznych, Poznań.

Nalaskowski A. (2006), Dzikość i zdziczenie jako kontekst edukacji, Kraków.

Nalaskowski A. (2009), Pedagogiczne złudzenia, zmyślenia, fikcje, Kraków.

Nalaskowski A. (2013), Ortodoksja i chaos, Kraków.

Nalaskowski A. (2020), Wielkie zatrzymanie. Co się stało z ludźmi?, Kraków.

Newcomb T.M., Turner R.H., Converse P.E. (1970), Psychologia społeczna: studium interakcji ludzkich, Warszawa.

Noske M. (2011), Problematyczna uniwersalność wartości uniwersalnych, Teraźniejszość - Człowiek - Edukacja: kwartalnik myśli społeczno-pedagogicznej, 3(55), s. 129-148.

Nowak M. (1996), Znaczenie wartości w procesie wychowania, [w:] K. Popielski (red.), Człowiek Wartości - Sens. Studia z psychologii egzystencji, Lublin, s. 241-259.

Nowak S. (1973), Pojęcie postawy $w$ teoriach i stosowanych badaniach społecznych, [w:] S. Nowak (red.), Teorie postaw, Warszawa, s. 17-69.

Olbrycht K. (1994), Edukacja aksjologiczna. Wymiary. Kierunki. Uwarunkowania, t. 1, Katowice.

Olbrycht K. (2002), Prawda, dobro i piękno w wychowaniu człowieka jako osoby, Katowice.

Ostrowska U. (2017), Aksjologia pedagogiczna - subdyscyplina naukowa pedagogiki (in statu nascendi), Roczniki Pedagogiczne, 9(2), s. 11-30.

Pasterniak-Kobyłecka E. (2018), O możliwościach edukacji aksjologicznej we współczesnej szkole, Prima Educatione, 2, s. 47-55.

Peeters M.A. (2010), Globalizacja zachodniej rewolucji kulturowej, Warszawa.

Rand A. (2003), Powrót człowieka pierwotnego: rewolucja antyprzemysłowa, Poznań.

Reykowski J. (1973), Postawy a osobowość, [w:] S. Nowak (red.), Teorie postaw, Warszawa, s. 89-121.

Siewiora J. (2017), Funkcje wartości w wychowaniu, Roczniki Pedagogiczne, 9(45), 2, s. 31-45.

Silverman D. (2012), Interpretacja danych jakościowych: metody analizy rozmowy, tekstu i interakcji, Warszawa.

Sztandar-Sztanderska K. (2010), Teoria praktyki i praktyka teorii. Wstęp do socjologii Pierre’a Bourdieu, Warszawa.

Świeca M. (2001), Wartości humanistyczne wyzwaniem dla edukacji, Acta Scientifica Academiae Ostroviensis, 8, s. 199-202.

Tyszkowa M. (1990), Zdolności, osobowość i działalność uczniów, Warszawa.

Wędzińska M. (2013), Człowiek na drodze do wartości. Myśl etyczna Maxa Schellera - implikacje pedagogiczne, Przeglad Pedagogiczny, 1, s. 31-43.

Wędzińska M. (2017), Preferencje wartości uczniów szkół ponadgimnazjalnych - próba charakterystyki, Przeglad Pedagogiczny, 2, s. 102-124.

Wędzińska M. (2018), Jakie wartości preferuje współczesna młodzież?, UczMy, 4, s. 7-10.

Wędzińska M. (2019a), Deficyty wartości a tendencja do zachowań o charakterze cyberbullyingu wśród młodzieży, [w:] M. Kamper-Kubańska, K. Kaszlińska, P. Sobierajski (red.), Wymiary bezpieczeństwa - ujęcie interdyscyplinarne, Toruń, s. 203-212.

Wędzińska M. (2019b), Wartości preferowane przez uczniów szkót ponadgimnazjalnych i ich rola w kształtowaniu postaw wobec osób z niepetnosprawnością ruchową, [w:] K. Wrońska (red.), Dobra edukacji i ich pedagogiczna eksploracja, Kraków, s. 395-414. 
Wędzińska M. (2020), Co jest ważne dla młodzieży? O preferencjach i roli wartości w życiu uczniów szkół ponadpodstawowych, Rocznik Towarzystwa Naukowego Płockiego, 12, s. 347-374.

Witkowski L. (2011), Historie autorytetu wobec kultury i edukacji, Kraków.

Witkowski M. (2010), Statystyka matematyczna w zarządzaniu, Poznań.

Witkowski L., Dudzikowa M. (2009), Wyzwania autorytetu w praktyce społecznej i kulturze symbolicznej (przechadzki krytyczne w poszukiwaniu dyskursu dla teorii), Kraków.

Znaniecki F. (1971), Nauki o kulturze, Warszawa. 